\title{
Social Media Marketing Perspectives in the Organization in Morelia, Mexico
}

\author{
Salvador Madrigal Moreno ${ }^{1}$, Gerardo Gabriel Alfaro Calderón ${ }^{1} \&$ Flor Madrigal Moreno ${ }^{1}$ \\ ${ }^{1}$ School of Accounting and Administrative Sciences, Universidad Michoacana de San Nicolás de Hidalgo, \\ Morelia, Michoacán, México \\ Correspondence: Salvador Madrigal Moreno, School of Accounting and Administrative Sciences, Universidad \\ Michoacana de San Nicolás de Hidalgo, Michoacán, México. E-mail: smadrigal@umich.mx
}

Received: January 21, 2016 Accepted: February 13, 2016 Online Published: March 25, 2016

doi:10.5539/ijms.v8n2p128 URL: http://dx.doi.org/10.5539/ijms.v8n2p128

\begin{abstract}
Social media marketing (SMM) is a reality in contemporary society. This research presents a review of the literature on the phenomenon of SMM to establish the challenges and opportunities social media faces. Subsequently, the digital inclusion in Mexico is discussed roughly focusing on the situation of SMM in the organization in Morelia. The purpose of this paper is to contextualize the use of social media and establish the challenges and opportunities of inclusion in communication strategies and marketing in the organization in Morelia. It is confirmed that the contemporary society has established the conditions to implement properly social media marketing in Morelia.
\end{abstract}

Keywords: social media marketing, digital inclusion, communication strategies

\section{Introduction}

In the context of contemporary society, information and communication technologies (ICT) have reshaped the social dynamics, and they have been placed as a central and decisive element in organizations. The new communication schemes have changed the dimensions of social and organizational life that seemed unchallengeable, like time, space and even the perception of reality. From the high ownership of mobile devices, like cell phones and tablets, the permanent availability is a fact. Social changes generated by ICTs have increased in this contemporary society that has empowered the customer in such a way that if an organization wishes to survive requires redesigning their communication and marketing strategies. That is, the organization must reduce their reliance on traditional tactics of mass communication and marketing; understanding the role of technology in the market and most importantly the participation of the social media as part of the toolbox of marketing that must be seen as an important strategy (Constantinides, 2014). Speaking of social media, this refers to the use of Internet-based and mobile devices to transform communication in a more interactive dialogue (Guliciuc, 2014). Alternatively, a group of Internet-based applications that are based on ideological and technological principles based on the Web 2.0 which allows the creation and exchange of user-generated content (Badea, 2014). When it comes to the use of social media to market-related objectives is when it is possible to talking about the social media as a marketing display.

As it occurs in any social phenomenon, social media marketing (SMM) involves a series of opportunities and challenges, which on their own, create the necessity to be contextualized in a very particular way. Digital inclusion is the key point to position marketing in the social media. This research provides an overview of the conditions that digital inclusion is facing in Mexico. Given the lack of research that reveal the SMM in Morelia, it is that this study is conducted to contextualize the phenomenon of SMM, and glimpse its potential in the organization of Morelia. In this paper, a conceptual, theoretical approach to the phenomenon of SMM is presented and then the assumption that different organizations in Morelia have about the research topic. The results obtained indicate that SMM is a feasible option for the organization of Morelia to establish a direct and permanent communication with any person they want so that the main risk of social media marketing for the organizations in Morelia is not to implement it.

\section{Methodology}

This is an exploratory, descriptive and quantitative research. By analyzing secondary information (books, 
magazines, journals and reports), it is possible to identify the challenges and opportunities the SMM is facing. Subsequently, through a survey used as a methodological tool a situational analysis of SMM in Morelia, Mexico was established. The survey was applied to 50 organizations in Morelia. The structure of the survey consists of 6 questions: the first question would determine whether the organization had the minimum requirements for installing social media as a marketing strategy. The second shows if the organization has already had any kind of participation in the social media; from the second question the survey would lead the researcher to know what the social media is most used by the organization on the one hand, and on the other hand, the reasons why they are not using the social networks.

The structured survey questions were formulated from the frequency of variables found in the literature and the information presented in the latest report from the report Habits of Internet Users in Mexico 2015, conducted by the Mexican Internet Association (AMIPCI, 2015). The main objective of the survey was to identify the level of appropriation of social media by organizations in Morelia. The study sample (not probabilistic for convenience) consisted of 50 organizations that were selected randomly, and due to some of them refused to participate in the research; the researcherusedthe snowball method.

\section{Social Media Marketing}

Due to the existing conditions of internet accessibility in Mexico and that Mexican people are more attracted to use them, it can be said that there are the necessary conditions to display any of the existing communication strategies and SMM. The SMM that can be very useful, due to a great number of advantages at a low cost, this thanks to the massive use of the Internet and mobile devices (cell phones, tablets), that represent many opportunities but also remove many threats (El-Gohary, 2010).

According to Efthymios Constantinides (2014) marketing, through social media can be performed under any of these strategies: 1) passive approach, focusing on the use of social media to give voice to the customer; and 2) the active approach, for example, participation in social networks and their use as marketing channels and direct public relations, as client channels of influence, as tools for clients personalization and last but not least, to develop them as platforms of cooperation and innovation generated by the customer.

Increasingly, the consumption is determined by computer- mediated environments; in which consumers see a space for self-definition and self-expression. SMM gives importance to these environments as they restored the time and space in a very different way, which attracts decisively to prosumers, particularly the young ones (Jensen, Schau, \& Gilly, 2003). The mixed marketing applied to SMM is an advantage because of the large potential market that represents the network. The ICTs and the implementation of digital marketing strategies provide a wide range of opportunities and challenges in virtual environments, demonstrating the importance of investing in activities such as SMM, as they are electronic activities with great economic power.

SMM is a new field and a new business practice where the marketing of goods, services, information and ideas are involved through the online media (Dahnil, Marzuki, Langgat, \& Fabeil, 2014). This is because the social media offers a unique method of marketing communication. SMM makes use of social networking applications as an extension to fulfill with a marketing strategy. Marketing activities in social media allow the production of information and collaboration between users. On the other hand, ownership of mobile technologies has allowed the interaction of different contents that can be shared, created, discussed and modified by the user.

Companies can, more accurately, predict future purchasing behavior of their customers, improve their positioning, attract new customers, build awareness, increase sales and retain customers more effectively (Dahnil et al., 2014). Also, social media has generated significant changes in the strategies and tools used by business organizations to communicate with users. Social media enables organizations to stay in touch with customers at the right time, directly and at lower costs and more efficiently than any other traditional communication tools (Hassan, Nadzim, \& Shiratuddin, 2015).

The use of social media can reduce the gap between the possibilities of investment and development of communication strategies and marketing between a large and a small company. However, for small companies, the use of social media marketing in business is still in its infancy (Hassan et al., 2015). The advantages of social media (easy and friendly to use are not- discriminatory means of communication) allow people with similar interests to find each other and to interact easily. From a business perspective, companies create a series of channels to collect and understand the requirements of consumers, and the social media is an excellent choice. Companies that have integrated SMM into their organization have employees and customers more willing to recommend the company to others.

The impact of social media activity in contemporary organizations is highly important and can be reflected not 
only in marketing but also in management, marketing and on the use of the ICTs for the organizational performance (Georgescu \& Popescul, 2015). Importantly, the organizational leadership directly affects the process of adoption of social media and its possible implementation on digital marketing. The administrator can lead to a greater level of commitment and participation among members and workers in their company and therefore, broader involvement in the use of the technology. Leaders who are well-informed about emerging technologies may lead other managers to consider their use, to positively influence the implementation of digital marketing, and support innovations (Dahnil et al., 2014). Companies that adopt SMM as part as their communication and marketing strategies is most of the time due to those entrepreneurs with an active, innovative attitude and the knowledge that allows them to see the adoption of ICTs for their companies favorably.

Although social media is a significant phenomenon of the information society, more research is needed on the strategic use of social media marketing (Hassan et al., 2015). Note that each context has its characteristics, and, therefore, each organization should design a particular social media environment, giving special attention to any of the elements that conform to it.

\subsection{Challenges and Opportunities of the Social Media Marketing}

The information society has contributed decisively to the appearance, expansion and social appropriation of the social media. However, it is not as simply as incorporate social media for fashion. The relevance of incorporating it into communication strategies and marketing of the organization is evident, but the manager must be cautious and careful to equally evaluate the risks of incorporating social media in the organization. Here the opportunities that the adoption of social media will be established. This latter comment was based on the review and analysis of relevant literature in the area.

Dilhan Öztamur \& Ibrahim Karakadılar (2014) state that most marketing practices for SMM involve the creation and operation of a company fan page, the promotion management, the maintenance of public relations, and conducting market research among other primary activities. Another important finding in Öztamur \& Karakadılar research (2014) corroborate that the establishment of SMM is ideal for implementing digital word of mouth (WOM) and viral marketing media strategies.

From a fully marketing point of view Öztamur \& Karakadılar (2014) focused the SMM opportunities as a potentially powerful means to influencers that generate consumption, linked to them and turn them into brand advocates. However, they point out that to create viral marketing and WOM campaigns, trust must be established and subsequently reinforced to overcome any reluctance on the part of potential consumers. Also, they place the role of social media as a consumer search engine. Before the positioning of new technologies and mobile devices, consumers have turned to social media to find information about companies. The way social media can establish trust with customers has no comparison in traditional media. The brand loyalty is positively affected by social networks (Erdoğmuş \& Çiçek, 2012). However, the consumer is not passive. Customers are asking for creative reasons, variety and differences to collaborate with brands in social media.

As a result of their research, Mircea Georgescu \& Daniela Popescul (2015) established that the vast ownership of social media and the high level of interaction have strongly influenced the business environment. That is consequently exposed to a paradigm change; where hierarchies crumble and communication and collaboration create wider links for employees and all partner organizations. Besides, they argue that modern organizations have increased the need to transfer information and knowledge that together represent a crucial critical factor in the business environment that today is dynamic and global. Their research also allows them to confirm that the social media lowers the barriers that may arise in the way knowledge is transferred; and that the development of ICT in modern society has led to a rapid appropriation of social networks. The friendly and readily understandable environment transmits unstructured information and knowledge of multiple experiences, which allows employees to communicate more efficiently, and also to open channels for transferring knowledge (Georgescu \& Popescul, 2015).

The strategic capacities that represent the social media marketing affect positively the brand innovation and acts as a moderator between the gaining of knowledge, market orientation, and the brand change. This latter comment is highlighted by Bang Nguyen, Xiaoyu Yu, T. C. Melewar, \& Junsong Chen (2015) in their recent research. In social networks, customer needs, either expressed or latent (or not expressed) can be identified better than in traditional media. Therefore, the context of social networks provides a different set of rules for competition and strategic behavior.

Marius Badea (2014) noted the benefits of positioning social media into the organization. The study by Badea acknowledged that social media can contribute internally in various dimensions of the organization like: improving communication, processes, community development, facilitating the flow of information, the 
promotion of values, the consolidation of organizational culture, stimulating creativity, and even the collective intelligence.

Germán Narvaez \& Edgar Montalvo (2014) carried out a research in which social media is seen as an excellent means for conducting market research. They therefore consider the strategic use of social networks is an additional tool of traditional marketing that can provide a competitive advantage. Through social networks can jointly create publicity among those involved in the marketing of the product of interest, which represents a saving in market research (Narvaez \& Montalvo, 2014). There is a big area of opportunity to educate small businesses about the potential that a good social media strategy for your business may represent. Many managers are unaware of the existence of tools that could be useful in their daily operations such as the promotion of their products, relationship with customers, track their strategies and measure their results and identify the brand positioning, etc.

However, inadequate management of social networks can negatively impact on the consumer.Once identified the advantages of social media, it is possible to determine and clarify the challenges social media faces in the organization of contemporary society.

One of the main challenges is that the implementation of social media as a tool for communication and marketing would not be seen as in isolation. On the contrary, to be considered as a process that represents the latest step in a coherent approach to improving the product/service strategic effort, the organization and the website. It is said that the Web 2.0 has empowered the client through a new generation of online applications, tools and business networking opportunities that are part of the social media (Constantinides, 2014). Social media today plays a very important and decisive role in the contemporary organization; it can be used as a substitute for the traditional tools that help dealers to conduct a series of marketing activities efficiently, very often with the active participation of customers.

Adopting the social media scheme, will not help the organization by itself to develop its potential unless there are changes in the organization processes that at the same time are supported by a dynamic of continuous improvement (Von Rosing, Scheer, von Scheel, Maamar, \& Von Rosing, 2015). There is a significant gap between the potential of social media and its use. However, economic power can limit an organization that uses social media as a means of promotion. Not all companies use social networks at least for product promotion.

Consequently, if consumers are not Internet users, the use of social media for promotional purposes is useless (as in the case of the rural population). The organization should consider whether social networks could be conveniently used in any way that permits brand positioning or for internal communication. Organizations should also consider whether they are ready to implement social media and be aware of which could be the possible barriers (Badea, 2014).

The prompt completion of a situational analysis of the organization will reveal factors that may impact the adoption of the ICTs and their use for the establishment of communication strategies and SMM. The Government, the public policies and various private sector initiatives influence the adoption of the ICTs. The basic infrastructure of the organization as well as the connection to high speed Internet will be crucial to encourage the use of technology. Moreover, it must be considered whether the market in which it competes, suppliers, partners, customers are ready and available to venture into digitalization. Even factors such as globalization, the economic situation, market behavior and culture are factors that impact on the adoption of SMM (Dahnil et al., 2014).

Other significant challenges in implementing the SMM in an organization as a strategic means of communication and marketing are the limitations for adopting it (users who do not know how to use social media or encountering difficulties in the adoption of technology), hesitation (that the user has a negative view of the potential of social media as a means of communication) or narrow conditions of adaptability in organizational structure, and the list could go on depending on the social, economic and cultural context in which the organization operates. Access to information has facilitated the transfer of knowledge between people, but there is a problem, not all people have access to ICTs. Along the gap with the developed world, there is a significant internal gap in accessing to the ICTs within each country, in particular in Latin America (Artopoulos, 2011). The great challenge of the organizations of the future is the development of organizational structures and processes flexible enough so they can meet the demands of communication in the era of social media (Badea, 2014). Below are two comparative tables (Tables 1 and 2) in which the opportunities and challenges of SMM are presented according to each author research. 
Table 1. Comparative studies on SMM opportunities

\begin{tabular}{|c|c|}
\hline El-Gohary, H. (2010). & $\begin{array}{l}\text { It requires little investment; benefits from increased use of the internet and } \\
\text { mobile devices. }\end{array}$ \\
\hline Jensen Schau, H., \& Gilly, M. C. (2003). & $\begin{array}{l}\text { Computer mediated environment exists; the consumer is already a } \\
\text { prosumer. }\end{array}$ \\
\hline Alipour, M., Hajaliakbari, F., \& Javanbakht, N. (2011). & It represents an economic potential for the organization. \\
\hline Hassan, S., Nadzim, S. Z. A., \& Shiratuddin, N. (2015). & $\begin{array}{l}\text { Establishes direct communication; allows ongoing communication; lower } \\
\text { costs than traditional media. }\end{array}$ \\
\hline Georgescu, M., \& Popescul, D. (2015). & $\begin{array}{l}\text { Supports the transfer of information and knowledge in more quickly way. It } \\
\text { lowers the barriers of time and space. It has a friendly atmosphere and is } \\
\text { easy to understand. It is more personal. It helps to build stronger } \\
\text { relationships with different audiences. It is not discriminatory and it } \\
\text { frameworks the organization. }\end{array}$ \\
\hline Apăvăloaie, E.-I. (2014). & Facilitates largest market (even global). \\
\hline $\begin{array}{l}\text { Dahnil, M. I., Marzuki, K. M., Langgat, J., \& Fabeil, N. F. } \\
\text { (2014). }\end{array}$ & $\begin{array}{l}\text { It permits an interaction with the prosumer; it is possible to understand the } \\
\text { buying behavior; attracts new customers; raises awareness; consumer } \\
\text { loyalty and it is not expensive. }\end{array}$ \\
\hline Constantinides, E. (2014). & $\begin{array}{l}\text { It gives voice to customer. It is a tool for public relations; it can be a tool } \\
\text { for product personalization. It generates cooperation and innovation. It } \\
\text { represents the best means for more sophisticated clients. }\end{array}$ \\
\hline Badea, M. (2014). & $\begin{array}{l}\text { Positions the brand and the company. It facilitates communication in the } \\
\text { organization; promotes values; consolidates the organizational culture. It } \\
\text { stimulates creativity and collective intelligence; encourages cooperation } \\
\text { among employees. It facilitates teleworking. }\end{array}$ \\
\hline Öztamur, D., \& Karakadılar, İ. S. (2014). & $\begin{array}{l}\text { It facilitates external communication strategies; it encourages word of } \\
\text { mouth (WOM) communication; it is an ideal medium for viral campaigns; } \\
\text { contributes to customer loyalty; it is a great tool for market research. }\end{array}$ \\
\hline Erdoğmuş, İ. E., \& Çiçek, M. (2012). & $\begin{array}{l}\text { Generates customer confidence; positively affects the brand and the } \\
\text { organization. }\end{array}$ \\
\hline Narváez, G. A., \& Montalvo, E. (2014). & $\begin{array}{l}\text { It is an excellent tool to attract and retain customers; It allows to know the } \\
\text { behavior of consumers and the market; allows market research at low cost. }\end{array}$ \\
\hline Nguyen, B., Yu, X., Melewar, T. C., \& Chen, J. (2015). & Positively affects brand innovation; identifies customer needs \\
\hline
\end{tabular}

Source: Original from the author, after literature consultation.

Table 2. Comparative studies of the challenges SMM is facing.

\begin{tabular}{ll}
\hline $\begin{array}{l}\text { Dahnil, M. I., Marzuki, K. M., Langgat, J., \& Fabeil, N. } \\
\text { F. (2014). }\end{array}$ & $\begin{array}{l}\text { The State, public policies and private sector initiatives can impact } \\
\text { negatively; there may be rejection by customers, employees, etc. Workers } \\
\text { may feel threatened; culture may limit its appropriation. }\end{array}$ \\
Badea, M. (2014). & $\begin{array}{l}\text { Digital gaps (useless in contexts without internet, people may not be } \\
\text { interested; possible rejection of workers; it creates uncertainty; the } \\
\text { organizational structure cannot be prepared; economic, social and cultural } \\
\text { context represent a barrier; uncertainty about the security of data handling; } \\
\text { there may be misused by employees. }\end{array}$ \\
& $\begin{array}{l}\text { Minimal investment is required. } \\
\text { The organizations cannot meet customer requirements; it requires creativity, } \\
\text { variety and differentiation. }\end{array}$ \\
Öztamur, D., \& Karakadılar, İ. S. (2014). & The digital and technological gap; ignorance about what social media is. \\
Erdoğmuş, I. E., \& Çiçek, M. (2012). & \\
\hline
\end{tabular}

Source: Original from the author, after literature consultation.

Although there are research and theories that support various aspects of social media is important to note the need to incorporate the unique aspects of each culture in which investigations have been completed. While there may be common ground, the particular context of each culture will establish the conditions to see if a message can be accepted and culturally significant (Dahl, 2015). Therefore, the phenomenon of social media should be studied in each particular culture.

\subsection{Internet users in Mexico}

Some authors highlight the digital gaps as one of the main challenges for SMM. With the intention to contextualize this challenge in Mexico, particularly in Morelia, the social media term will be roughly presented. The Organization for Economic Co-operation and Development (OECD) defines the digital gap as a difference between individuals, households, businesses and geographic areas at different socioeconomic levels regarding 
the opportunities to access ICTs and Internet use (Palacios \& Flores-Roux, 2013). It is desirable to segment the digital gap into three types:

1). Market gap: is the difference between the existing levels of penetration and those that potentially can be achieved.

2). Access gap: given their socio-economic conditions there are some sectors of the population that cannot access to digital services even at prices that reflect market efficiencies. To solve this, it is necessary the intervention of the state. These interventions are usually given through subsidies to users and operators, or through public investments.

3). Gap of ownership: who will use the technology must know how to use it.

Now, to set the landscape and environment of the phenomenon of social media in Mexico and its organizational impact (challenges and opportunities), some hard data will be presented about the use of the Internet and its penetration in Mexican society. According to the 11th study on the Habits of Internet Users in Mexico 2015, conducted by the Mexican Internet Association (AMIPCI, 2015) indicates that in Mexico there are 53.9 million internet users, $50 \%$ male and $50 \%$ female. From these, there are people who at least once a month use the Internet, despite their location. According to the same study, Mexico is already above the $50 \%$ of penetration among the population aged 6 and older. The daily average connection time is 6 hours and 11 minutes.

Most of the places where Mexican Internet users connect are $84 \%$ at home, at work $42 \%$, and school $36 \%$. The penetration and positioning of mobile devices have increased the internet connection, $35 \%$ of users said they can connect anywhere mainly thanks to smartphones, $58 \%$ of Mexican Internet users connect from their smartphone, surpassed only by another mobile device such as laptops with the $68 \%$ of users.

Another point to note is that Mexico occupies the 11th position among the countries with the highest number of Internet users in the world (WIP, 2013). The report by the AMIPCI shows that the primary use of Internet is to connect to social networks, followed by the search for information and finally to send emails. It is remarked that social networks have been positioned by Mexican users as one with the highest activity among others. However, only $18 \%$ of business uses the Internet to manage social networking company. So there is a wide gap between the use of social networking and appropriation of these by organizations and their use channels of communication and marketing, both internally and externally.

Moreover, 93\% of Internet users access social networks; being Facebook the top one. On the other hand, Twitter and Instagram have gained prominence thanks to the positioning of cell phones. $45 \%$ of Internet users are loyal followers of a brand in social networks (WIP, 2013). Social networks have quickly been appropriated by Mexicans. According to the latest report presented by the World Internet Project (WIP, 2013), Mexican Internet users spend on an average of 41.3 hours a week connected to the Internet, which by far surpasses the exposure to traditional media such as radio, television or press. This has led to a reconfiguration in the distribution of advertising and direct marketing investment. Moreover, the Internet has emerged as the primary media of entertainment and information. Another important element that has made consider the Internet as one of the main media is the exponential growth of mobile devices that has led to the rise of multitasking; for instance, mobile devices have allowed users to face media and Internet simultaneously. Then the most relevant data of the digital environment in Mexico is shown in Table 3.

Table 3. Internet users in Mexico

\begin{tabular}{ll}
\hline Internet users & 59.3 million \\
Internet users gender & $50 \%$ male, $50 \%$ female \\
Internet diffusion in Mexico & More than $50 \%$ \\
Average time of Internet connection & 6 hours y 11 minutes \\
Places & Home $84 \%$, \\
& Work $42 \%$, \\
& School $36 \%$, \\
Devices & Others $35 \%$ \\
& $68 \%$ Laptop \\
Use of Internet & $58 \%$ Cell phones \\
Use of social media by organizations & $93 \%$ Use social networks \\
Social media & $18 \%$ \\
Internet users that follow a brand & Facebook \\
\hline
\end{tabular}

Source: Original from the author. Adapted from AMIPCI (2015) and WIP (2013). 


\section{Results}

Figure 1 shows how all of the organizations that participated in this study claimed to have mobile devices (smartphone, laptop, tablet or computer) with Internet access. However, they do not use these devices to implement SMM into their organizations. Therefore, it states that the digital gap in this case is not due to a digital gap for access, but to a digital gap ownership; to say, they have the possibility, but not the ability.

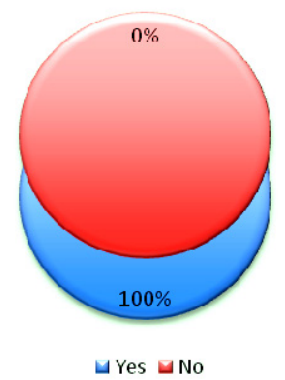

Figure 1. Internet access of the organizations in Morelia

Regarding the presence that organizations have in virtual social networks, Figure 2 shows that just around the $50 \%$ of them already have a presence in virtual environments, but $46 \%$ do have not found an area of opportunity for them.

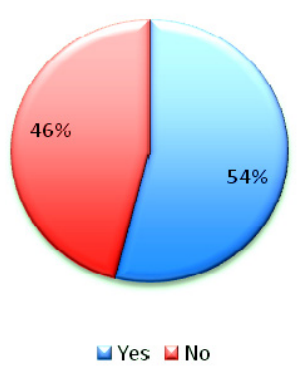

Figure 2. Presence of the organization in Moreliain social media

As mentioned in the methodology, from the third question in the survey it is possible to establish which organizations already use social networks and who does not, to obtain meaningful information, Figure 3 shows whichare the most used social networks by organizations in Morelia. Facebook, Twitter, and Instagram are confirmed as the social networks most used by organizations in Morelia.

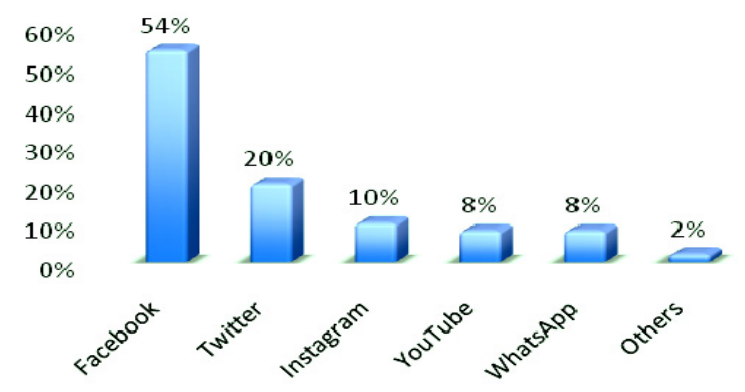

Figure 3. Most used social networks in the organization in Morelia

Although there is a social networking presence in the $54 \%$ of the organizations in this study, there are few that make proper use of them to implement SMM strategies. Some of them are present in social networks, but do not use them. Figure 4 shows how some organizations are simply there, watching. 


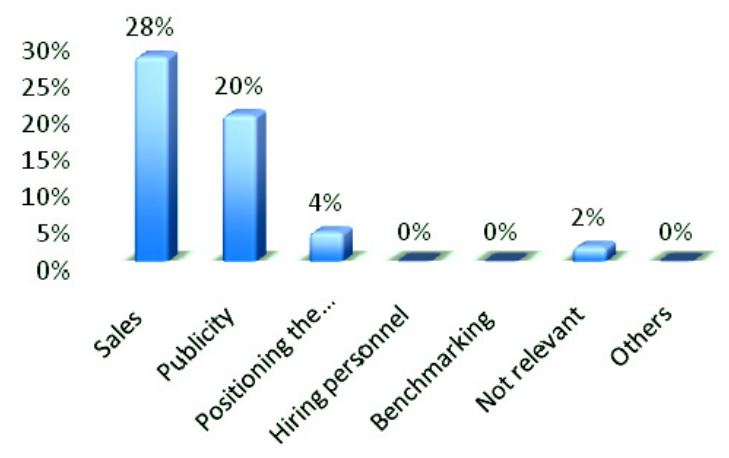

Figure 4. Main uses of social networks in organizations in Morelia

Moreover, the information on why the $46 \%$ of the organizations interviewed do not use social networks are illustrated in Figure 5. Here it is shown why and despite having the opportunity to have a presence on the social networks, some organizations in Morelia choose not to use them.

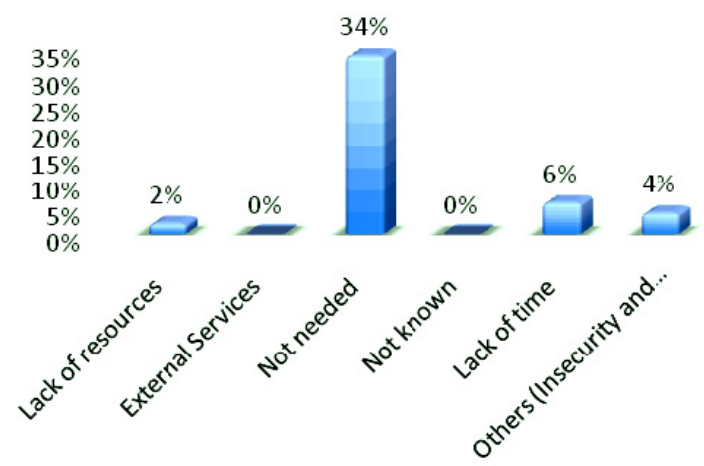

Figure 5. Reasons not to use social media networksin organizations in Morelia

Finally, in Figure 6 the potential uses envisioned by the organizations are shown. Note that most of the organizations interviewed explain how do some benchmarking over their competitors through social media marketing might be possible.

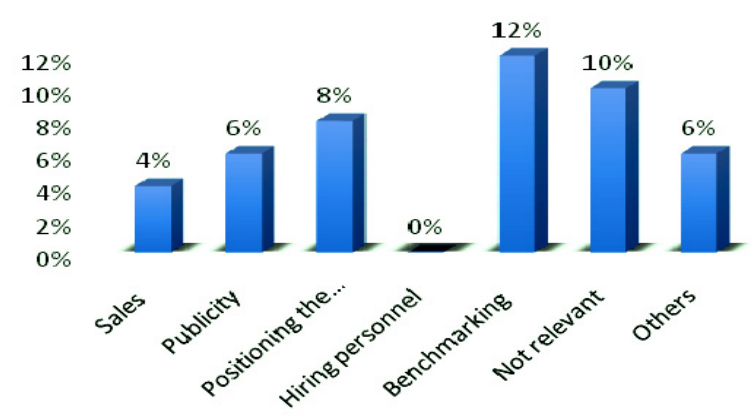

Figure 6. Possible uses of SMM to organizations in Morelia

As it is shown, $100 \%$ of the surveyed organizations have the possibility of using social media as marketing strategies; however, only $54 \%$ have a presence in social media. Facebook is the most used social network, followed by Twitter and Instagram. The primary use given to social networks is for sales and advertising. However, there is some reluctance to use social networks in the organization due to they do not need them, although these organizations claim that they could use social media networks for benchmarking. 


\section{Conclusions}

Social media represents an opportunity to maximize the communication strategies in the organizations and, so does the SMM. Mexico has Internet diffusion in more than the 50\% of its territory and more than 53 million people use the Internet. Mexican people have made the social media and new technologies part of their daily lives. This research validated that the opportunities of establishing SMM strategies in organizations are superior to the challenges it faces. The conditions for digital inclusion in Mexico are also favorable. There is a considerable digital gap in Morelia, but not in accessing to social media, but market and ownership. This allows for more research that permits to generate models that minimize the gap of ownership and to reduce the gap in market conditions.

Now, in the case of the organizations in Morelia, there is an appropriation of social media networks of more than the $50 \%$, but their use is limited to sales and advertising. Building stronger relationships with customers and users is important. The future paradigm of marketing is based on the transparency, cooperation, co-creation and a sincere commitment to listen and help, rather than to control, the client (Constantinides, 2014). Social media is already an agent of change and a source of opportunities for marketing policymakers who will learn to operate in a new business environment that to put the customer back into the top of organization priorities. The study met the objectives: to describe the challenges and opportunities the social media marketing is facing, digital inclusion context in Mexico, and to identify the ownership of social media in the organization in Morelia. However, the information collected only allows incompletely observe the phenomenon and poses many questions to establish continuousness to this research.

\section{Recommendations}

This research sets the basis to investigate the phenomenon of SMM in the organization in Morelia from different perspectives. A choice of possible exploration opens: it would be interesting to investigate how important are the skills in social media networks from those who lead organizations in Morelia. The ownership of social networks in the consumers in Morelia, what is the impact of public policies and how to develop strategies that could link marketing to traditional media with social media networks. Social media has not finished setting up their role in the organization, and therefore requires special investigation because it is not just to replicate content. Participation in social media requires interaction and permanent reconfiguration commitment. Some opportunities for further research include studies of the SMM in the region, not all the cities have the same digital inclusión; periodic follow up studies of SMM in Morelia; and studies of SSM in organizations of the same commercial sector.

\section{References}

Alipour, M., Hajaliakbari, F., \& Javanbakht, N. (2011). The Impact of Web-Marketing Mix (4s) on Development of Tourism Industry in Iran. International Journal of Business and Social Science, 2(6), 267-274.

AMIPCI. (2015). 11o Estudio sobre los hábitos de los usuarios de internet en México 2015. México. Retrieved from https://amipci.org.mx/images/AMIPCI_HABITOS_DEL_INTERNAUTA_MEXICANO_2015.pdf

Apăvăloaie, E.-I. (2014). The Impact of the Internet on the Business Environment. Procedia Economics and Finance, 15, 951-958. http://doi.org/10.1016/S2212-5671(14)00654-6

Artopoulos, A. (2011). La Sociedad de las Cuatro Pantallas: Una mirada latinoamericana. Buenos Aires: Ariel.

Badea, M. (2014). Social Media and Organizational Communication. Procedia - Social and Behavioral Sciences, 149, 70-75. http://doi.org/10.1016/j.sbspro.2014.08.192

Constantinides, E. (2014). Foundations of Social Media Marketing. Procedia - Social and Behavioral Sciences, 148, 40-57. http://doi.org/10.1016/j.sbspro.2014.07.016

Dahl, S. (2015). Social Media Marketing. Theories \& Applications. London: SAGE Publications.

Dahnil, M. I., Marzuki, K. M., Langgat, J., \& Fabeil, N. F. (2014). Factors Influencing SMEs Adoption of Social Media Marketing. Procedia - Social and Behavioral Sciences, 148, 119-126. http://doi.org/10.1016/j.sbspro.2014.07.025

El-Gohary, H. (2010). E-Marketing-A literature Review from a Small Businesses perspective. International Journal of Business and Social Science, 214-244. Retrieved from http://www.ijbssnet.com/journals/20.pdf

Erdoğmuş, İ. E., \& Çiçek, M. (2012). The Impact of Social Media Marketing on Brand Loyalty. Procedia Social and Behavioral Sciences, 58, 1353-1360. http://doi.org/10.1016/j.sbspro.2012.09.1119

Georgescu, M., \& Popescul, D. (2015). Social Media - The New Paradigm of Collaboration and Communication 
for Business Environment. Procedia Economics and Finance, 20, $277-282$. http://doi.org/10.1016/S2212-5671(15)00075-1

Guliciuc, V. (2014). Complexity and Social Media. Procedia - Social and Behavioral Sciences, 149, $371-375$. http://doi.org/10.1016/j.sbspro.2014.08.193

Hassan, S., Nadzim, S. Z. A., \& Shiratuddin, N. (2015). Strategic Use of Social Media for Small Business Based on the AIDA Model. Procedia - Social and Behavioral Sciences, 172, 262-269. http://doi.org/10.1016/j.sbspro.2015.01.363

Jensen Schau, H., \& Gilly, M. C. (2003). We Are What We Post? Self-Presentation in Personal Web Space. Journal of Consumer Research, 30(3), 385-404. http://doi.org/10.1086/378616

Narváez, G. A., \& Montalvo, E. (2014). Best Practice in the Use of Social Networks Marketing Strategy as in SMEs. Procedia - Social and Behavioral Sciences, 148, 533-542. http://doi.org/10.1016/j.sbspro.2014.07.076

Nguyen, B., Yu, X., Melewar, T. C., \& Chen, J. (2015). Brand innovation and social media: Knowledge acquisition from social media, market orientation, and the moderating role of social media strategic capability. Industrial Marketing Management. http://doi.org/10.1016/j.indmarman.2015.04.017

Öztamur, D., \& Karakadilar, İ. S. (2014). Exploring the Role of Social Media for SMEs: As a New Marketing Strategy Tool for the Firm Performance Perspective. Procedia - Social and Behavioral Sciences, 150, 511-520. http://doi.org/10.1016/j.sbspro.2014.09.067

Palacios, J., \& Flores-Roux, E. (2013). Diagnóstico del sector TIC en México Conectividad e inclusión social para la mejora de la productividad y el crecimiento económico. México.

Von Rosing, M., Scheer, A.-W., von Scheel, H., Maamar, Z., \& Von Rosing, M. (2015). The Complete Business Process Handbook. The Complete Business Process Handbook, $377-394$. http://doi.org/10.1016/B978-0-12-799959-3.00018-5

WIP. (2013). Estudio de hábitos y percepciones de los mexicanos sobre Internet y diversas tecnologías asociadas. México. Retrieved from http://wip.mx/

\section{Copyrights}

Copyright for this article is retained by the author, with first publication rights granted to the journal.

This is an open-access article distributed under the terms and conditions of the Creative Commons Attribution license (http://creativecommons.org/licenses/by/3.0/) 